\title{
Microbiological Aspects of Cleaning Validation During the Production of Dietary Supplements
}

DAVOR J. KORČOK, Abela Pharm, Belgrade
Original scientific paper

UDC: 615.3 .076

661.12

DOI: 10.5937/tehnika2002255K

\begin{abstract}
Dietary supplements as pharmaceutical dosage forms, can be found commercially available in online pharmacies, drugstores and other establishments. They represent foods that supplement the normal diet and are concentrated sources of nutrients (vitamins, minerals, and other nutrients or physiological effects), marketed in dosage forms designed to be taken in prescribed amounts (capsules, tablets, drops, etc.). The purpose of this paper is to validate the cleaning process of the production line for the production of solid pharmaceutical forms. The aim of the research is to determine the effectiveness of the proposed measures by the validation of the cleaning process from the microbiologic perspective, as well as to define the time of the status of "clean" equipment, i.e. reliable and safe work on multifunctional equipment, a process in which there is no cross-contamination of one product with residues of another. The validation has clearly and unequivocally demonstrated that one production line for the production of solid pharmaceutical preparations may produce more products on the same line even if it also produces probiotic preparations which are normally considered believed to require a separate production facility. Continuous monitoring of the effectiveness of the validated cleaning procedure should be carried out at defined intervals after production of the selected product.
\end{abstract}

Key words: cleaning validation, microbiology, food supplements

\section{INTRODUCTION}

Dietary supplements are concentrated sources of nutrients or other substances with nutritional or physiological effects that are considered to be foods, although they are marketed as pharmaceutical dosage forms (European Food Safety Authority). The main reason for the use of dietary supplements is to preserve health and vitality, or in other words, to prepare the body for a later period of life, but also through dietary supplements can prevent the appearance or affect the degree and course of various diseases.

Dietary supplements can be divided into several categories based on the ingredients they contain:

- vitamins and minerals

- multivitamins and minerals - they usually contain recommended daily dose of vitamins with the addition of minerals;

Author's address: Davor Korčok, Abela Pharm doo, Belgrade, Viline vode bb

e-mail: davorkorcok@abelapharm.rs

Paper received: 16.03.2020.

Paper accepted: 31.03.2020.
- individual vitamins and minerals - may contain large amounts of minerals;

- a combination of vitamins and minerals that can be targeted at specific population groups (athletes, children, pregnant women, breastfeeding women...);

- combination of vitamins and minerals with other substances;

- natural oils containing fatty acids;

- herbal ingredients;

- enzymes with known effects but with significant results when taken for several months;

- amino acids or amino acid derivatives;

- probiotic cells and prebiotic ingredients.

According to some studies it has been established that the main reason for the use of these preparations is to maintain health and the desire to prepare the body for later life. In dietary supplements, herbal drugs are in doses lower than therapeutic, but this does not mean that no side effects and certain interactions can occur, especially if these preparations are used for a long period of 
time. The basic requirement for a dietary supplement to be marketed is to be of good quality, effective and safe. In order to meet the basic requirements, it is necessary to adopt legislation with precisely defined quality and safety conditions[1].

Hazard is a biological, chemical or physical property in finished products that may cause the product to malfunction. When conducting a hazard analysis in production of dietary supplements, it is necessary to assess the risk involved in the likelihood that these hazards will occur, as well as their severity, if they actually occur.

To effectively eliminate them, the hazards must be so defined that their prevention, elimination or reduction to acceptable levels is practically possible. A number of factors such as ingredients, processing, distribution and intended use of the product must be taken into account.

Product safety hazards can be classified as microbiological, chemical and physical.

A critical indicator of the safety of using dietary supplements is microbiological quality. These microbiological changes affect the therapeutic potency and dosage delivery[2].

Biological hazards are manifested through the presence of bacteria, viruses and parasites. These organisms are often present in humans and in raw materials but must be avoided in finished products.

Examples of the most frequent hazards from the group of microbiological, chemical and physical hazards are presented in Tables 1,2 and 3.

Table 1. Microbiological hazards

\begin{tabular}{|l|l|l|}
\hline Type of danger & Sources & Examples \\
\hline Pathogens & $\begin{array}{l}\text { Raw material, } \\
\text { employees, } \\
\text { environment, dirty } \\
\text { water }\end{array}$ & $\begin{array}{l}\text { Salmonella, } \\
\text { Staphylococcus } \\
\text { aureus, } \\
\text { Clostridium }\end{array}$ \\
\hline Algae & water & Intoxication \\
\hline Fungi & Nuts, dry ingredients & Mycotoxins \\
\hline
\end{tabular}

Table 2. Chemical hazards

\begin{tabular}{|l|l|l|}
\hline Raw material & Process & Packaging \\
\hline Pesticides & Cleaning agents & Pacificators \\
\hline Heavy metals & Lubricants & Ink \\
\hline Natural toxins & Allergens & Glue \\
\hline Allergens & Gasses & Metals \\
\hline Antibiotics & Additives & - \\
\hline
\end{tabular}

Table 3. Physical hazards

\begin{tabular}{|l|l|l|}
\hline Material & Possibility of injury & Packaging \\
\hline Glass & Injury, bleeding & Bottles \\
\hline Wood & - & - \\
\hline
\end{tabular}

Cross-contamination in the manufacture of pharmaceuticals poses one of the greatest risks for patients, and the opportunities for it to occur in a pharmaceutical facility are numerous and arise from both technical and organizational disadvantages. Insufficient cleaning of production equipment, poorly designed plant and inadequate HV$\mathrm{AC}$ system are possible reasons as well as contamination transmitted through personnel or materials (for example contamination of primary packaging material). Likewise, the design of the production process can itself be a cause of cross-contamination: for example, exposure of the product to the environment when transferring to other production equipment.

Although it may also be referred to as the term contamination, the term cross-contamination implies only the inter-contamination of the starting material, intermediate or finished product with another substance or product during manufacture. Whereas the term contamination refers to contamination by various impurities, chemical or microbiological in nature, starting materials, intermediate products or active components during production, sampling, packaging or repackaging, storage or transport.

Based on the defined research objectives, and in accordance with the subject of the research, a hypothetical research framework is proposed. Through validation of the cleaning process, we prove that the production line for the production of solid pharmaceutical forms on which the following product is produced, and after the production of the worst case selected, is not:

- contaminated with microorganisms.

\section{CLEANING VALIDATION}

Although cleaning validation is a formally defined and well-recognized requirement by regulatory authorities, it is still a problem for many manufacturers and inspectors. The European GMP [1] requires that Production equipment must be designed, housed and maintained in a manner that is appropriate for its intended purpose. The equipment must be installed in a manner that prevents any risk of error or contamination. Repair and maintenance procedures must not pose a risk to the quality of the 
product. „European GMP also requires that" Production equipment must be designed in such a way as to allow its easy and complete cleaning.

The primary goal and benefit of cleaning validation is to:

- Identifies and corrects a potential problem that may affect the safety, efficiency or quality of the next batch of products to be manufactured on the same equipment.

- Ensure compliance with national regulations.

If a good cleaning validation program is used, several serious problems can be avoided:

- Cross-contamination with active components of manufactured drugs on the same equipment.

- Contamination with other materials (equipment lubricants, cleaning agent residues, cleaning accessories particles, equipment scraps).

- Microbial contamination

The validation of cleaning must be based on sound scientific reasoning with clear explanations. Validation of the cleaning process is performed to confirm the effectiveness of the cleaning procedure for the appropriate equipment. The validation of the cleaning process is part of the validation that provides a documented record that the cleaning procedures consistently remove chemical substances and microbial load to pre-determined limits, and that the approved cleaning process will provide equipment suitable for the manufacture of medicines.

Validation of cleaning procedures includes the following aspects:

- Visual inspection of surfaces in contact with the product, as well as surfaces not in contact with the product, to visually determine the possible presence of traces of the previous product.

- Presence of active component residues.

- Chemical and microbiological aspects.

The validation of cleaning must be based on sound scientific reasoning with clear explanations. Validation of the cleaning process is performed to confirm the effectiveness of the cleaning procedure for the appropriate equipment. The validation of the cleaning process is part of the validation that provides a documented record that the cleaning procedures consistently remove chemical substances and microbial load to pre-determined limits, and that the approved cleaning process will provide equipment suitable for the manufacture of medicines.

For microbiological analysis brushes or contact plates sample critical areas of equipment that are difficult to clean and that have come into contact with the product. Sampling sites as well as sampling methods must be clearly defined. Samples are tested for residues of the active component of the drug that was last manufactured on that equipment.

Sterile swabs are sampled for selected equipment surfaces, and then the number of colonies formed (CFUs) is determined. The sampling sites and methods must be clearly defined and described in a separate procedure. If the presence of a single colony is determined, appropriate tests must be performed to identify the micro-organisms.

\subsection{Strategy and results of cleaning validation}

Validation of the cleaning process is specific to the product and equipment and involves cleaning processes after each of three consecutive batches (or three cycles in the case of campaign production). The cleaning procedure is considered valid if the cleanings after three consecutive batches of selected worst case have consistently reduced the potential contaminants to a predetermined level of acceptability.

The sampling areas (sites) were previously selected as the worst cases during the washing process. Certain risk factors have been identified: solubility, pharmacology and formulation.

Considering the represented risk factors for products made on the Solid Preparation Production Line, it is concluded that the worst case is Bulardi ${ }^{\circledR}$ Probiotic capsules, because it has Saccharomyces boulardii in its composition, which is a type of yeast with characteristics characteristic of probiotics and as such is insoluble in water and suitable for the development of microorganisms, that is, its residues on the equipment lead to microbiological contamination of the following product.

Sampling for determining the microbiological load of the equipment is carried out by swabbing or taking a certain amount of purified water from the final washing of the equipment and washing the surfaces from inaccessible places. Swabs are taken with sterile swabs with cotton or synthetic material (alginate or rayon), which are moistened with sterile $1 \%$ peptone water or sterile saline with $1 \%$ peptone or saline that will not inhibit microbial growth. The swab is pressed against the wall of the tube for the excess liquid to drip off.

The sample is taken from the restricted area by rotating the swab from left to right and from right to left five times and up and down five times. After sampling, the swab is placed in a test tube containing $10 \mathrm{ml}$ of sterile $1 \%$ peptone water or sterile saline with $1 \%$ peptone water or saline. With each set of samples, a negative blank sample is sent to 
the laboratory. The area to be sampled should be 20 $\mathrm{cm}^{2} \mathrm{P}$. When a rough surface is sampled, a flexible template is used to limit the area to be sampled. For sampling carried out by taking a certain amount of purified water from the final flushing of the equipment, or by washing the surfaces for inaccessible places, a labelled conical flask is used. $100 \mathrm{ml}$ of purified water is sampled from final flushing of equipment (part of equipment) or from flushing surfaces from inaccessible places. The validation protocol of the cleaning process will accurately define the sampling method for a specific sampling site (swab or rinse / flush). Samples are transported to the laboratory at $10 \mathrm{C}$ to $40^{\circ} \mathrm{C}$. Bacteriological testing should be started as soon as possible and no later than 24 hours after sampling. Protective masks, gloves and suits must be used when sampling.

Pursuant to the Risk Analysis for the Purpose of Cleaning Process Validation, RA_AP_003, rev.00, the subject of validation of the cleaning process of a production line for the manufacture of solid preparations after the production of Bulardi ${ }^{\circledR}$ Probiotic capsules was:

Determination of the microbiological load of the equipment:

- An overview of the detergents, rinses and disinfectants used during the validation of the cleaning process, as defined in the written procedures and in CLEAN report [3].

- Deconex Surfax, Deconex Cip-o-cid, Deconex Surface AF (Internal method 7/22/2015).

- Deconex Surfax, Deconex Cip-o-cid, Deconex Surface AF(Internal method 22/07/2015).

- Deconex Surfax, Deconex Cip-o-cid, Deconex Surface AF, Deconex Formula 1, and purified water. (Internal method 22/07/2015).

- Deconex Surfax, Deconex Cip - o - cid, Deconex Surface AF, Deconex Formula 1 (Internal method 22/07/2015).

Table 4. Microbiology sampling spots on equipment used to produce solid forms

\begin{tabular}{|l|l|l|}
\hline Equipment name & $\begin{array}{l}\text { Number of sampling } \\
\text { spots }\end{array}$ & $\begin{array}{l}\text { Microbiological } \\
\text { smear }\end{array}$ \\
\hline Mixer & 3 & MB1, MB2 (2) \\
\hline Blistering machine & 3 & MB3,MB4, MB5 (3) \\
\hline $\begin{array}{l}\text { Encapsulating } \\
\text { machine }\end{array}$ & 10 & $\begin{array}{l}\text { MB6,MB7,MB8, } \\
\text { MB9,MB10, MB11, } \\
\text { MB12 (7) }\end{array}$ \\
\hline $\begin{array}{l}\text { Sieve, diameter 2 } \\
\text { mm }\end{array}$ & 2 & MB13 (1) \\
\hline Total & 18 & 13 \\
\hline
\end{tabular}

Eligibility criteria for microbial load: Sampling with smears of surfaces in contact with the product: $\leq 10 \mathrm{CFU} / \mathrm{cm}^{2} \mathrm{PP}\left(\leq 200 \mathrm{CFU} / 20 \mathrm{~cm}^{2} \mathrm{P}\right) \mathrm{P}$, in accordance with the Food Safety Act (Official Gazette of the Republic of Serbia, No. 41/2009) and the Guide for the Application of Microbiological Food Criteria (Republic of Serbia, Ministry of Agriculture, Trade, Forestry and Water Management, first edition, July 2011).

\section{Materials and methods for the analysis of microbiology smears (MB)}

Sterile swabs with cotton wool or synthetic material (alginate or rayon) [4], which were soaked in sterile saline, were used for sampling. After sampling, the swab was placed in a sterile saline tube. With each set of samples, a negative blank sample was sent to the laboratories. The sampled area was $100 \mathrm{~cm}^{2}$.

- The total number of aerobic mesophilic microorganisms was determined by the horizontal method for determining the number of microorganisms by counting colonies at $30^{\circ} \mathrm{C}$ by surface inoculation technique- EN ISO 4833-2 2014 [5].

- Determination of Enterobacteriaceae by horizontal method for detection and determination of Enterobacteriaceae by colony counting method - EN ISO 21528-2 2009 [6].

Table 5. Acceptance criteria Results

\begin{tabular}{|l|l|}
\hline Name & Criteria \\
\hline & $\begin{array}{l}\text { Acceptance criterion for } \\
\text { microbiological swabs for contact } \\
\text { surfaces on equipment: aerobic } \\
\text { mesophilic bacteria } \leq 10 \text { CFU / } \\
\text { burden }\end{array}$ \\
& $\begin{array}{l}\mathrm{cm}^{2} \text { and Enterobacteriaceae } 0 \text { to } 1 \\
\mathrm{CFU} / \mathrm{cm}^{2}\end{array}$ \\
\hline
\end{tabular}

\subsubsection{Results}

Immediately before production (up to $1 \mathrm{~h}$ ), microbiological swabs were sampled and the number of aerobic mesophilic bacteria was determined in the samples.

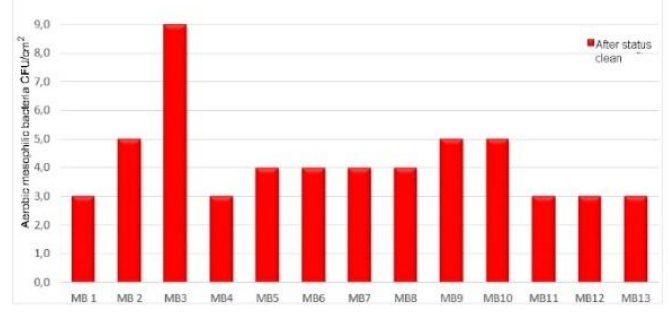

Figure 1 - Graphic representation of results MB1MB13 of microbiology testing during the first test 
The results obtained are shown graphically in Figure 1. The results for all specimens of microbial swabs for Enterobacteriacae number were not graphically presented and were $<1 \mathrm{CFU} / \mathrm{cm}^{2}$.

The second test was followed by the cleaning effects after three consecutive Bulardi ${ }^{\circledR}$ Probiotic batches. The same sampling points as in the first test were sampled, but after treating of equipment by certified cleaning agents and during statuses: dirty status of $8 \mathrm{~h}$ $\pm 2 \mathrm{~h}$ and clean status of $12 \mathrm{~h} \pm 4 \mathrm{~h}$.

Visual inspection has previously determined that the equipment is subjectively clean and results for aerobic mesophilic bacteria counts are shown in Figure 2. Results for all Enterobacteriaceae microbial swab samples were not graphically presented and were $<1$ $\mathrm{CFU} / \mathrm{cm}^{2}$.

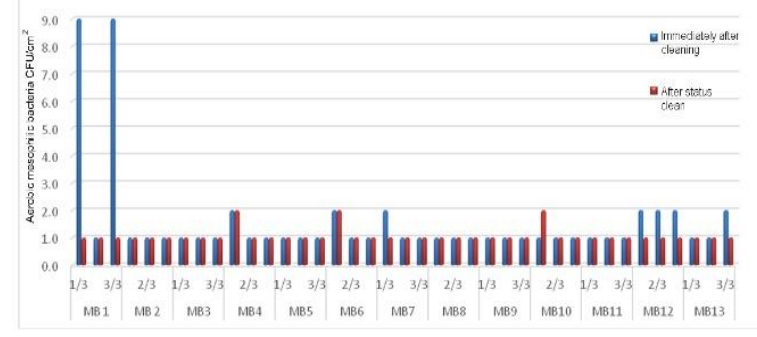

Figure 2 - Graphic representation of results $M B 1$ MB13 of microbiology testing during the second test

The result analysis obtained by the first examination of microbiological parameters, during three consecutive cleanings of the solid capsule preparation line after the production of Bulardi ${ }^{\circledR}$ Probiotic capsules, shows:

- The microbiological load of swabs, for aerobic mesophilic bacteria, (acceptability criterion $\leq 10$ $\mathrm{CFU} / \mathrm{cm}^{2}$ ) and for Enterobacteriaceae (acceptability criterion $<1 \mathrm{CFU} / \mathrm{cm}^{2}$ ), at all sampling sites, was within the limits after the cleaning process and after a defined status time. During the first test (the number of aerobic mesophilic bacteria is in the range 3 to $9 \mathrm{CFU} / \mathrm{cm}^{2}$ ).

Analysis of the results obtained from the second examination of chemical and microbiological parameters, during three consecutive cleanings of the production line of solid preparations-capsules after the production of the selected worst case Bulardi ${ }^{\circledR}$ Probiotic capsule, shows:

- the microbiological load of swabs, for aerobic mesophilic bacteria, (acceptability criterion $\leq 10 \mathrm{CFU}$ $/ \mathrm{cm}^{2}$ ) and for Enterobacteriaceae (acceptability criterion $<1 \mathrm{CFU} / \mathrm{cm}^{2}$ ), at all sampling points was within the limits immediately after the cleaning process and after a defined status time and the results show a slightly lower microbial load than the first test (in the first test, 9 results were above $3 \mathrm{CFU} / \mathrm{cm}^{2}$ and in the second only two results were above $3 \mathrm{CFU} / \mathrm{cm}^{2}$ ).

- decrease in microbiological load, i.e. the number of aerobic mesophilic bacteria after certain time period of equipment for a definite status of clean, up to $16 \mathrm{~h}$, is most pronounced at the following sampling points: MB1, MB7, and MB13, most likely due to the bactericidal and bacteriostatic disinfectant action.

- other microbiological sampling sites show uniform results within the limits, after cleaning as well as sampling after clean status. The microbiological load was slightly lower during the second test (the number of aerobic mesophilic bacteria was reduced to $1 \mathrm{CFU} /$ $\mathrm{cm}^{2}$ in most samples), indicating more efficient cleaning and rinsing using proper operating instructions with purified water and certified agents.

\section{CONCLUSION}

The primary task of pharmaceutical manufacturers is to market a safe, quality and efficient product that can only be achieved if all standard operating procedures are clearly defined and if all of the necessary qualifications and validations required by the GMP inspector have been implemented. Cleaning validation is only one of the validation processes in the production of pharmaceuticals and is indispensable because it represent evidence that the cleaning procedures of production equipment are adequate and whether a product of expected quality or a product that meets specifications will be obtained.

Here, the microbiological aspects of validation of the cleaning process in pharmaceutical practise was carried out without any inconsistencies, objections and corrective measures and it is considered that the cleaning validation was successfully implemented and completed. The validation has clearly and unequivocally demonstrated that one product line for the production of solid pharmaceutical preparations may produce more products and if the same line also produces probiotic preparations which are considered to be produced in a separate production facility.

It is proven that the multifunctional production line after the production of the selected worst case Bulardi ${ }^{\circledR}$ Probiotic capsule was not contaminated with the detergents, microorganisms and residues of the previously manufactured product selected as the worst case by risk analysis. 


\section{ACKNOWLEDGEMENT}

The authors declare no conflict of interest.

\section{REFERENCES}

[1] EudraLex (the Rules Governing Medicinal Products in the European Union), Volume 4, EU Guidelines to Good Manufacturing Practice Medicinal Products for Human and Veterinary Use, 2008.

[2] Dlugaszewska J, Ratajczak M, Kamińska D, Gajecka $\mathrm{M}$,Are dietary supplements containing plant-derived ingredients safe microbiologically? Saudi Pharmaceutical Journal, Vol. 27, Issue 2, pp. 240-245, February 2019 .

[3] CLEAN Report Abela Pharm-Borer Chemie AG (July 2014)
[4] Sandle T. A practical Approach to the Selection of Cleanroom Disinfectants, [Internet], Dostupno na: https://www.pharmafocusasia.com/articles/practical-approach

[5] ISO 4833-2:2013 Microbiology of the food chain - Horizontal method for the enumeration of microorganisms - Part 2: Colony count at 30 degrees $\mathrm{C}$ by the surface plating technique; ISO 4833-2:2013/Cor 1:2014 Technical Corrigendum 1.

[6] ISO 21528-2:2017 (Corrected version 2018-0601) Microbiology of the food chain - Horizontal method for the detection and enumeration of Enterobacteriaceae - Part 2: Colony-count technique.

\section{REZIME}

\section{MIKROBIOOLSKI ASPEKTI VALIDACIJE ČIŠĆENJA U TOKU PROIZVODNJE DIJETETSKIH SUPLEMENATA}

Dijetetski suplementi kao farmaceutsko dozirani oblici se mogu naći u slobodnoj prodaji u apotekama, na internetu, drogerijama i drugim objektima. Predstavljaju namirnice koje dopunjuju normalnu ishranu i predstavljaju koncentrovane izvore nutrijenata (vitamina, minerala i drugih supstanci sa hranljivim ili fiziološkim efektom) a и prometu su u doziranim farmaceutskim oblicima dizajniranim tako da se uzimaju u odmerenim pojedinačnim količinama (kapsule, tablete, kapi i sl). Predmet istraživanja ovog rada je validacija čišćenja proizvodne linije za izradu čvrstih farmaceutskih oblika. Cilj istraživanja je utvrđivanje efikasnosti predviđenih mera postupkom validacije procesa čiščenja sa mikrobiološke perspektive, kao i definisanje vremena statusa „čisto“ opreme odnosno pouzdan i bezbedan rad na multifunkcionalnoj opremi, proces pri kojem ne dolazi do unakrsne kontaminacije jednog proizvoda reziduama drugog. Validacijom je jasno i nedvosmisleno dokazano da na jednoj proizvodnoj liniji za proizvodnju čvrstih farmaceutskih preparata može da se proizvodi više proizvoda i ako se na istoj liniji proizvode i probiotski preparati za koje se smatra da se moraju proizvoditi u odvojenom proizvodnom pogonu. Kontinuirano praćenje efikasnosti validirane procedure čišćenja potrebno je obavljati u definisanim vremenskim intervalima nakon proizvodnje nakon proizvodnje odabranog proizvoda.

Ključne reči: validacija čišćenja, mikrobiologija, dijetetski suplementi 